\title{
Use of Coreference in Automatic Searching for Multiword Discourse Markers in the Prague Dependency Treebank
}

\author{
Magdaléna Rysová \\ Charles University in Prague \\ Faculty of Arts \\ [magdalena.rysova@post.cz]
}

\author{
Jiří Mírovský \\ Charles University in Prague \\ Faculty of Mathematics and Physics \\ [mirovsky@ufal.mff.cuni.cz]
}

\begin{abstract}
The paper introduces a possibility of new research offered by a multi-dimensional annotation of the Prague Dependency Treebank. It focuses on exploitation of the annotation of coreference for the annotation of discourse relations expressed by multiword expressions. It tries to find which aspect interlinks these linguistic areas and how we can use this interplay in automatic searching for Czech expressions like despite this (navzdory tomu), because of this fact (díky této skutečnosti) functioning as multiword discourse markers.
\end{abstract}

\section{Introduction}

The aim of the paper is to introduce possibilities of interplay between two linguistic phenomena - discourse $^{1}$ and coreference relations - annotated in the Prague Dependency Treebank (PDT). The paper demonstrates how the annotation of coreference relations (finished in 2011) may facilitate automatic searching for alternative lexicalizations of discourse connectives like due to this fact (kvůli této skutečnosti), in addition to this (kromé toho) in the corpus that offers annotation of several linguistic phenomena at once. In other words, the paper tries to show how we can build on existing annotation of coreference to improve another level of annotation - discourse.

\subsection{Annotation of Discourse Relations in the Prague Dependency Treebank}

The Prague Dependency Treebank is a corpus of almost 50 thousand sentences of Czech journalistic texts that offers linguistic data manually annotated on three layers - it interlinks morphological, syntactic and complex semantic (or tectogrammatic) annotation (Hajič et al., 2006, Bejček et al., 2012). For the semantic layer of PDT, there also exists annotation of coreference (Nedoluzhko et al., 2011), and discourse (as the only annotated corpus of Czech; see Poláková et al., 2012a).

Discourse relations are marked between two verbal arguments (i.e. two relevant parts of text) if they are signalled by a certain discourse marker - see an example from PDT:

(1) The mattress was terrible, no quality at first sight.

However, he did not care.

(In original: [Matrace] byla na první pohled strašná, nekvalitní. On na to ale vi̊bec nedbal.)

This work is licenced under a Creative Commons Attribution 4.0 International License. Page numbers and proceedings footer are added by the organizers. License details: http://reativecommons.org/licenses/by/4.0/

${ }^{1}$ In this paper, we understand discourse in narrow sense, i.e. as text relations between sentences (verbal arguments). Coreference is here used as an umbrella term for grammatical and textual coreference and bridging relations expressed in section 4 . Although bridging relations differ from coreference in traditional sense, as they express an indirect relation based on association, we use the general term coreference in the text for better transparency. 
In this example, there are two verbal arguments: the first is the mattress was terrible, no quality at first sight ([matrace] byla na prvni pohled strašná, nekvalitni) and the second he did not care (on na to ale vủbec nedbal). Between these two arguments, there is a discourse relation of opposition signalled by the conjunction however (ale). Therefore, in this case, however (ale) has a function of discourse marker.

In the first phase of discourse annotation (see the Prague Discourse Treebank 1.0, Poláková et al., 2012a), only discourse relations (between verbal arguments) introduced by explicit connectives have been captured. Explicit connectives are understood as closed class expressions with connecting function at the level of discourse description (see Poláková et al., 2012b) belonging among certain parts of speech - especially conjunctions (therefore, however, or - proto, ačkoli, nebo), adverbs (then, afterwards - potom, $p a k$ ) and particles (mainly rhematizers as too, only-také, jen).

However, during annotation, there occurred also other expressions exactly with the same connecting function that differed from connectives in both lexical and syntactic aspect. These expressions were called alternative lexicalizations of discourse connectives (shortly AltLexes) in the Penn Discourse Treebank ${ }^{2}$ (see Prasad et al., 2010); their examples are this is the reason why (to je důvod, proč), due to this fact (kvi̊li tomu) etc. In some cases, explicit discourse connectives and their alternative lexicalizations are even interchangeable - see an example from PDT:

(2) Almost every mined diamond has a quality of a jewel.

This is the reason why such an expensive output from the sea is worth for the company.

(In original: Téměř každý vytěžený diamant má kvalitu drahokamu.

To je důvod, proč se tak nákladná těžba z moře firmě vyplácí.)

In this example, there is an AltLex this is the reason why (to je divvod, proč) signalling a discourse relation of reason and result. This AltLex is replaceable by the connective therefore and the meaning remains exactly the same.

The example demonstrates that a complete discourse annotation should contain also relations expressed by AltLexes. Therefore, a detailed research on AltLexes is useful and needed. In this respect, the present paper tries to demonstrate how the new instances of Czech AltLexes may be automatically found in the Prague Dependency Treebank on the basis of the already finished coreference annotation.

\section{Alternative Lexicalizations of Discourse Connectives in PDT}

Alternative lexicalizations of discourse connectives were firstly described in detail for English (see Prasad et al., 2010). English AltLexes were examined from the lexico-syntactic and semantic point of view. Similar analysis has been made also for Czech (see Rysová, 2012a) - the research was carried out on the basis of the annotated data from PDT.

In the first stage of discourse annotation in PDT (i.e. annotation of Czech data), the annotators (trained students of linguistics) were asked to fill a comment "AltLex" to such expressions that function in the text, according to their interpretation, as Czech AltLexes. The aim of the first stage (regarding the AltLexes) was to collect an adequate sample of material that allowed the preliminary analysis of Czech AltLexes (see Rysová, 2012a).

Altogether, PDT contains 49,431 sentences with the annotation of discourse. Within them, there were 306 expressions (or tokens) with the annotators' comment "AltLex". This number seems to be rather low. However, the annotators did not mark all instances of AltLexes - in the first stage, the aim was not a final and complete annotation (as Czech AltLexes are a new and uninvestigated topic) but a collection of material for further research. So for example, we found out that the Czech AltLex because of (diky) appears in PDT in 14 instances although firstly, it was marked in the annotators' comment just in one case.

\footnotetext{
${ }^{2}$ The terms AltLex's and explicit discourse connectives are used in the Prague Dependency Treebank and Penn Discourse Treebank not fully identically. For example, Penn Discourse Treebank captures prepositional phrases as connectives whereas Prague Dependency Treebank as AltLex's etc. However, both understand connectives as closed class expressions and AltLex's as open class expressions with connecting function at the level of discourse.
} 
Therefore, it is obvious that the preliminary number 306 of Czech AltLexes will considerably grow and that in the following stage of annotation, it is necessary to search for Czech AltLexes more systematically.

\section{A Specific Group of Czech AltLexes: Preposition + an Anaphoric Expression}

On the basis of the 306 tokens gained from the first stage of annotation, there was created a preparatory list of Czech AltLexes (see Rysová, 2012b). It appeared that one significant group of them is formed by Czech prepositions followed by an anaphoric expression referring to the previous argument. These are expressions like because of this (kvi̊li tomu), due to this fact (díky této skutečnosti), despite this situation (navzdory této situaci) etc. - see an example from PDT:

(3) President Fernando Collor probably hoarded millions to his own pocket. Because of this, he is supposed to fail.

(In original: Prezident Fernando Collor si údajně nahrabal do vlastni kapsy milióny. Kvůli tomu pravděpodobně padne.)

In the example, there is a discourse relation of reason and result introduced by the AltLex because of this (kvili tomu) that is replaceable by the connective therefore (proto) in this case.

In this group of AltLexes, it is the preposition that carries the core of lexical meaning as well as the property of being an AltLex (see Rysová, 2012b). It means that the preposition carries the information about the type of the discourse relation - e.g. the example (3) demonstrates that it is the expression because of (kvulit) that signals a relation of reason and result and therefore the preposition is also the fixed part of the AltLex. At the same time, the preposition obligatorily combines with an anaphoric reference that may vary - in the example (3), it is the pronoun this (tomu) but it is variable with other anaphoric expressions, so there are such variants of AltLexes like because of this / this fact / this situation (diky tomu / této skutečnosti / této situaci) etc.

Other examples of prepositions (meant in the Czech originals - see Kroupová, 1984) from this group of AltLexes are in addition to (kromé), due to (kvůli), unlike (na rozdil od), on the basis of (na základè), despite (navzdory), in spite of (přes), due to (vinou), considering (vzhledem $k$ ).

As said above, these types of AltLexes must combine with some complementation due to their valency. Therefore, it is impossible to use, for example, *because of, I will do it (*kvůli to udělám), but only because of this, I will do it (kvưli tomu to udélám). So if there is some obligatory complementation, i.e. a general rule in all of these AltLexes, we may use this information for their automatic searching.

Moreover, all of these prepositions function as AltLexes only if they combine with some anaphoric expression referring to the previous argument. If they occur with a non-anaphoric expression, they are not AltLexes, like in this example:

(4) I was ill a whole month.

I could not sleep due to cough at night.

(In original: Marodila jsem celý měsic.

V noci jsem nemohla spát kvưli kašli.)

It is obvious that the expression due to cough (kvůli kašli) from the second sentence does not refer to any part of the previous one and that it does not signal any discourse relation between the two sentences. On the contrary, there is the following example of the same preposition with anaphoric reference functioning as AltLex:

(5) Italy saves.

Because of this, some journals will no longer come out. 


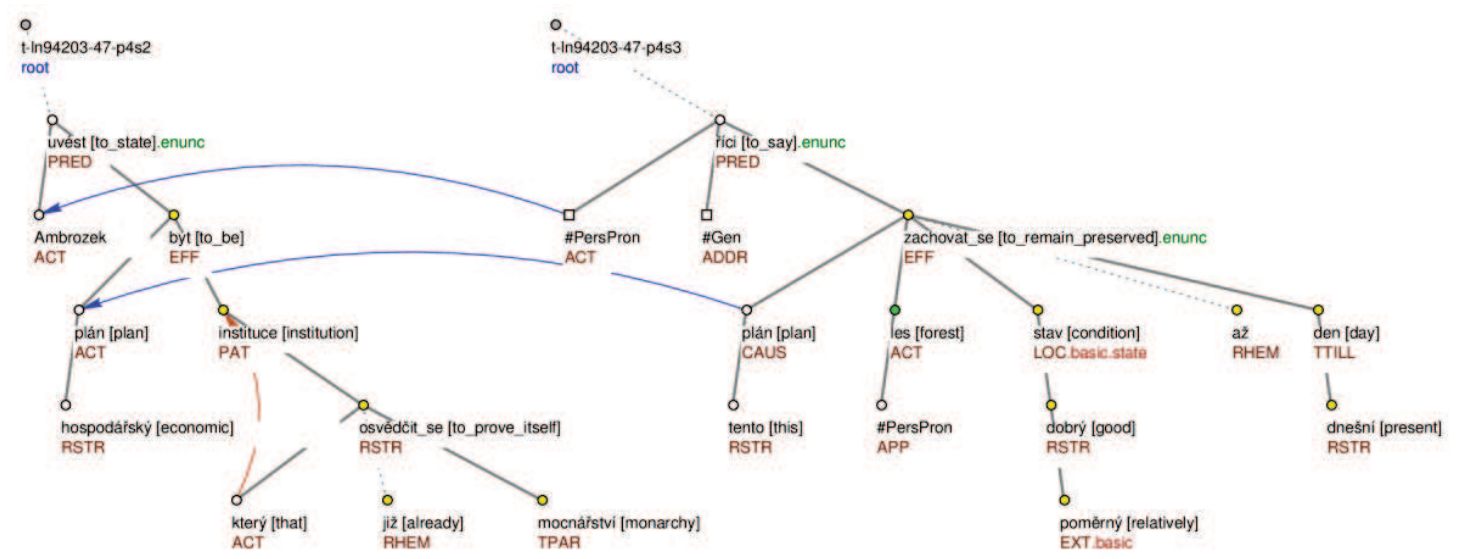

Figure 1. An example of a textual coreference with a noun as the antecedent.

(In original: Itálie šetř́.

Kvůli tomu tam přstanou vycházet některé deniky.)

In this example, the whole expression because of this (kvili tomu) introduces a discourse relation of reason and result between the two arguments. We may replace it, for example, by the connective therefore (proto).

It is obvious that combination of prepositions as due to ( $k v u i l i)$, because of (diky) with an anaphoric reference is, for them, a condition for being AltLex. This condition may be well used especially in corpora with annotated coreference as the Prague Dependency Treebank.

\section{Annotation of Coreference in PDT and Its Use for Discourse}

\subsection{Types of Coreference}

Annotation of coreference in PDT was finished in 2011 (cf. Nedoluzhko et al., 2011). The annotated relations are divided into four groups: a) grammatical coreference - mostly inter-sentential coreference derivable using Czech grammatical rules (the vertical arrow in Fig. 1); b) textual coreference - inter- and intrasentential coreference of pronouns and nouns derivable only from the sentence meaning (the horizontal arrows in Fig. 1); c) bridging anaphora - inter- and intra-sentential relations such as part-whole, subsetset, function etc.; d) special types of reference (exophora - referring to elements outside the text, and segment - referring to an unspecified larger part of the preceeding context) (see Nedoluzhko, 2011).

\subsection{AltLexes - Coreference Leading to the Verbal Argument}

As said in the section 3, there is one group of Czech AltLexes functioning as discourse markers only in combination with some anaphoric expression. The second condition is that this anaphoric expression must refer to a (whole) verbal argument. PDT captures it in the tree structure with the highest verbal node representing the whole argument (discourse relations are realized by thick orange arrows leading between two verbal nodes symbolising the two arguments). ${ }^{3}$ It means that when searching for tokens from this group of AltLexes, we may omit anaphoric expressions referring to non-verbal parts of text - see an example from PDT, depicted in Figure 1:

\footnotetext{
${ }^{3}$ It is important to understand that coreference and all discourse relations, although technically annotated between two nodes, in fact express a relation between the whole subtrees of the two nodes, as (on the tectogrammatical layer of PDT) a node represents the whole subtree it governs. (In case of discourse, more complex arguments can be specified in a dedicated attribute range.)
} 
(6) Ambrozek stated that the economic plan is an institution that proved itself already in the monarchy.

Because of this plan, our forests remained preserved in a relatively good condition until the present days, he said.

(In original: Ambrozek uvedl, že hospodářský plán je instituce, která se osvědčila již za mocnářství. Díky tomuto plánu se naše lesy zachovaly v poměrně dobrém stavu až do dnešních dnů, rekl.)

In the example, there is the preposition because of (diky) that combines with the anaphoric expression this plan (tento plán). However, this plan (tento plán) does not refer to the whole previous argument (sentence) but only to its nominal part plan (plán) - it means that there is annotated a coreference relation between these two nouns (see Figure 1 and the dark curved arrow between the two nodes plan in the two trees). Therefore, the expression because of this plan (diky tomuto plánu) is not an AltLex here.

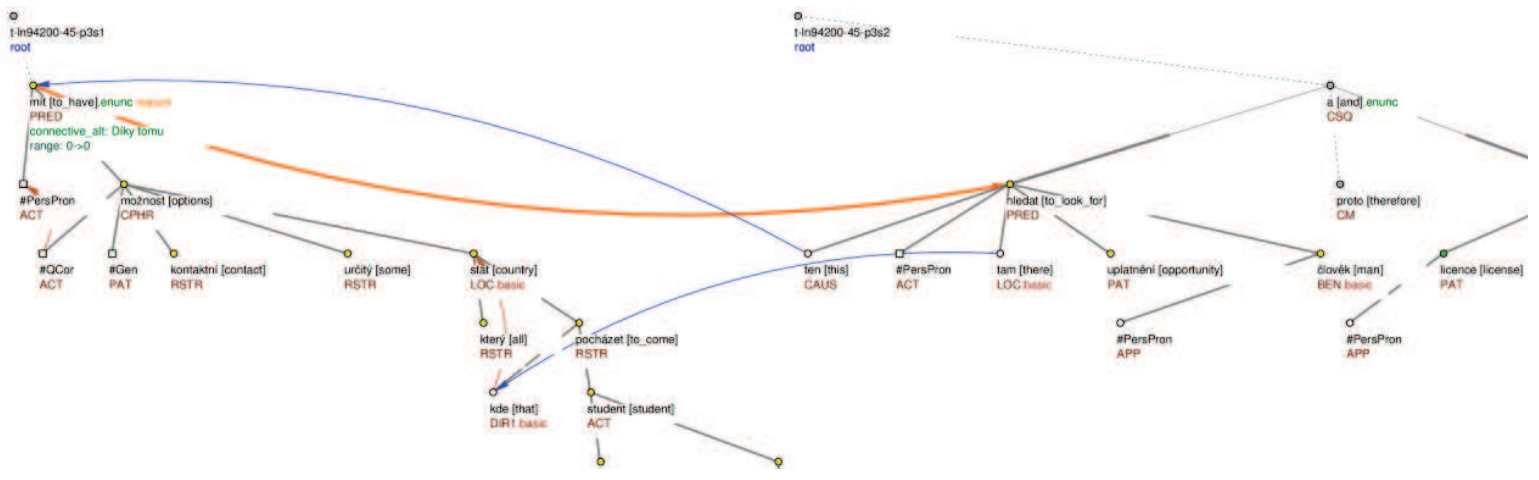

Figure 2. An example of a coreference to a verbal node. The trees have been cropped to fit the page.

On the other hand, there is another example, depicted in Figure 2:

(7) We have some contact options in all countries that foreign students in the former Czechoslovakia came from.

Because of this, we might be able to look there for opportunities for our people, and our license is therefore designed quite broadly.

(In original: Máme určité kontaktni možnosti ve všech státech, odkud pocházeli zahranični studenti v bývalém Československu.

Díky tomu bychom tam mohli hledat uplatnění pro naše lidi, a naše licence je proto pojata dosti široce.)

Again, there is the preposition because of (diky) with an anaphoric expression this (tomu) that, in this case, fulfils also the second condition, as it refers to the whole previous argument (sentence) represented by the finite verb in the main clause to have (mit) - see Figure 2 with the annotated coreference relation going from this (ten) to a verb to have (mit). The discourse relation is represented by a thick orange arrow going from the verb to have (mit) to a verb to look for (hledat).

These examples demonstrate that tokens of this type of AltLexes in PDT may be automatically looked up on the basis of the two conditions: a) the preposition must combine with an anaphoric expression; b) this expression must be in a coreference or bridging relation (according to the finished annotation of coreference - see Nedoluzhko et al., 2011) with some verbal node (representing the whole argument).

\subsection{Searching in the Data}

The primary format of PDT is called Prague Markup Language (PML). It is an abstract XML-based format designed for annotation of treebanks. For editing and processing data in the PML format, a highly 
customizable tree editor $\operatorname{TrEd}^{4}$ was developed (Pajas and Štěpánek, 2008). The search was performed in PML Tree Query (PML-TQ) ${ }^{5}$, a powerful client-server based query engine for treebanks (Pajas and Štěpánek, 2010), with the client part implemented as an extension to the tree editor TrEd.

Using the query engine, we searched for places in the data with a given preposition and an anaphoric expression relating to a verbal node either as grammatical coreference, textual coreference, bridging anaphora, or coreference to segment. The antecedent of the relation could either be directly the verbal node or a coordination or apposition of verbal nodes, or it could be unspecified in case of coreference to segment.

Let us present a simplified example of such a query; this particular query searches for relevant places in the PDT data with a preposition due to (vinou) plus an anaphoric expression:

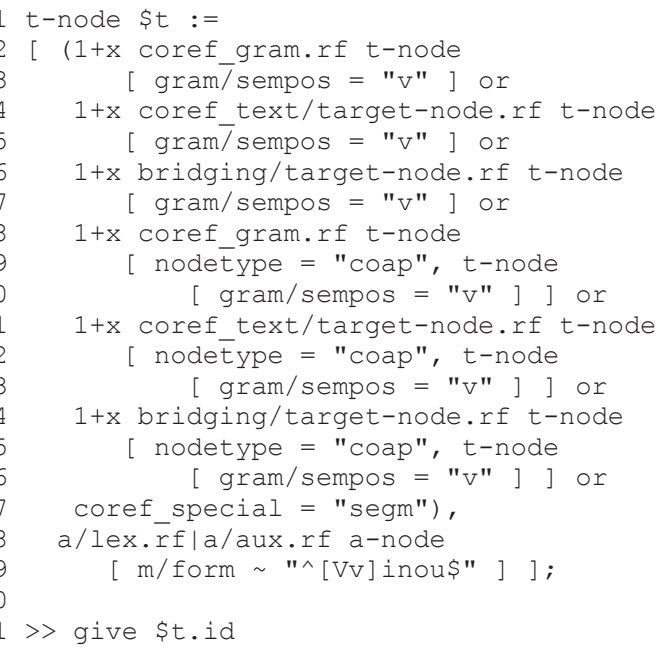

Line 1 declares a tectogrammatical node (and names it $\$$ t for later reference), lines $2-17$ specify a disjunction of seven possible ways of an anaphoric reference (lines 2 and 3 define a grammatical coreference from the given node to a verbal node (semantic part-of-speech equals "v"), lines 4 and 5 define the same condition for textual coreference, lines 6 and 7 for bridging anaphora. Lines 8-16 express the same three relations, this time with an anaphoric verbal node being a part of a coordination or apposition (the relation is between the given node $\$ t$ and the node representing the coordination or apposition (nodetype="coap")), and line 17 searches for a coreference to a not further specified segment). Lines 18 and 19 express that on the surface, the given node \$t represents the preposition due to (vinou). Finally, an output filter on line 21 gives identifiers of positions in the data found by the query.

For each preposition from a given list (see Table 1 below), the query produced a list of positions in the data. These positions were gone through by human annotators and discourse relations with all required additional information were marked there.

\subsection{Results, Evaluation and Discussion}

Altogether, PDT contains 1,482 tokens of selected prepositions (we worked with the types of prepositions that were, in some instances, marked as AltLexes in the preliminary phase of annotation). Within them, we have automatically looked up 89 instances functioning as AltLexes.

The results demonstrate that using coreference annotation significantly helped reduce the final number of relevant instances (i.e. those being AltLexes) and that it substantially facilitated the annotation of discourse (instead of 1,482 instances, the human annotators had to go only through 89 of them, i.e. only through $6 \%$ out of the total number in the whole PDT) - see Table 1 that introduces the total number of all instances of given prepositions (in any role) in PDT and their final reduced numbers in the role of Alt-

\footnotetext{
${ }^{4} \mathrm{http}: / /$ ufal.mff.cuni.cz/tred/

${ }^{5}$ http://ufal.mff.cuni.cz/pmltq/
} 
Lexes. So, for example, the preposition in addition to (kromé) appears altogether in 309 instances in PDT, within which there are 44 instances in the function of AltLex (automatically looked up). All automatically retrieved instances have then been manually checked and validated.

\begin{tabular}{|c|c|c|}
\hline Preposition & $\begin{array}{c}\text { Instances as } \\
\text { AltLexes }\end{array}$ & Total \\
\hline Because of $($ díky) & 14 & 191 \\
\hline In addition to $($ kromé) & 44 & 309 \\
\hline Due to $($ kvi̊li) & 5 & 130 \\
\hline Unlike $($ na rozdíl od) & 1 & 95 \\
\hline On the basis of $($ na základé) & 7 & 167 \\
\hline Despite $($ navzdory) & 2 & 30 \\
\hline In spite of $($ přes $)$ & 9 & 389 \\
\hline Due to $($ vinou $)$ & 1 & 14 \\
\hline Considering $($ vzhledem $k)$ & 6 & 157 \\
\hline Total & $\mathbf{8 9}$ & $\mathbf{1 4 8 2}$ \\
\hline
\end{tabular}

Table 1. Occurrences of AltLexes in the data of PDT

\subsubsection{Reliability of Coreference in the Annotation}

We are aware of the fact that our method is dependent on the good annotation of coreference and that if there are some mistakes on the level of coreference, they will mirror also in discourse, logically. Therefore, we have chosen one preposition (because of / diky) and manually checked all its tokens in PDT to examine the validity of searching for AltLexes on the basis of coreference.

We found out that coreference in PDT is annotated reliably. Within 191 of all instances, there were 35 with annotated coreference relations (14 leading to a verbal node, 21 to a non-verbal node) and 156 without any annotated relation. Within these 156 instances $^{6}$, we found only 3 disputable cases where the coreference could be annotated. However, these examples are definitely not clear cases of coreference, but they are rather questionable - see one of the examples from PDT:

(8) Their immortality is born from the blood until John begins to age incredibly fast.

Because of his disease, also a young doctor Sarah is pulled inevitably to a fatal whirl of bloody passions and mystery of life and death...

(In original: $Z$ krve se rodi jejich nesmrtelnost až do doby, než John začne neuvěřitelně rychle stárnout. Díky jeho chorobě je do osudového víru krvavých vášní a tajemství života i smrti neodvratně vtažena také mladá lékařka Sarah...)

It is disputable whether the expression his disease (jeho chorobè) is interpretable as coreferential to John begins to age incredibly fast (John začne neuvěřitelně rychle stárnout). We consider this example ambiguous and therefore the annotation of similar examples is dependent on the decision of the individual annotator. Moreover, it is disputable whether we can consider expressions like because of his disease (diky jeho chorobě) to be discourse markers. Also other data from PDT demonstrated that AltLexes of this type mostly contain rather general and abstract words like these facts / this situation / this problem (tyto skutečnosti / tato situace / tento problém).

\subsubsection{Difference between the Preliminary and Final Annotation}

The final number of AltLexes like due to this (vinou toho), despite this (navzdory tomu) found in PDT using the queries is 89 . Some of them have been captured already in the preliminary annotation - it means

\footnotetext{
${ }^{6}$ The instances have been discussed by two trained linguists.
} 
they were provided with the annotators' comment AltLex. There were altogether 306 of such comments in PDT, i.e. expressions that were interpreted as AltLexes (of all types, not only the prepositions) by first annotators. In the section 2, we demonstrated that this number is rather approximate, as not all instances of AltLexes have been captured. For illustration, see Table 2 for prepositions with preliminary numbers of tokens that had the comment AltLex after the first phase of annotation. The table shows that the preliminary annotation captured only 9 out of 89 final AltLex instances of prepositions. It means that the real number of this AltLex type grew almost ten times.

\begin{tabular}{|l|c|c|}
\hline \multicolumn{1}{|c|}{ Preposition } & $\begin{array}{c}\text { Annotated as AltLex in the } \\
\text { preliminary annotation }\end{array}$ & $\begin{array}{c}\text { Final number of AltLex } \\
\text { instances }\end{array}$ \\
\hline Because of $($ diky) & 1 & 14 \\
\hline In addition to $($ kromé) & $0(1)^{7}$ & 44 \\
\hline Due to $($ kvůli) & 2 & 5 \\
\hline Unlike $($ na rozdíl od) & 1 & 1 \\
\hline On the basis of $($ na základé) & 1 & 2 \\
\hline Despite $($ navzdory) & $0(1)$ & 9 \\
\hline In spite of $($ pres $)$ & 2 & 1 \\
\hline Due to $($ vinou $)$ & 1 & 6 \\
\hline Considering $($ vzhledem $k)$ & 1 & $\mathbf{8 9}$ \\
\hline Total & $\mathbf{9}$ & \\
\hline
\end{tabular}

Table 2. Difference between the preliminary and final annotation in numbers

\section{Conclusion}

The paper demonstrates the possibilities of using the present annotation of the Prague Dependency Treebank for practical annotations of discourse relations. The aim of the paper was to introduce how we can use the annotation of coreference for searching for the so called alternative lexicalizations of discourse connectives like considering this situation (vzhledem k této situaci), on the basis of this (na základè toho). In this way, we significantly reduced the amount of manual annotation work, as we demonstrated in the evaluation part.

This method may be used not only for prepositions like due to (diky), but also for all other multiword discourse markers containing an anaphoric expression, for example verbs like this means (to znamená), this leads to (to vede $k$ ), this is related to (s tim souvisi) etc. for which the presence of an anaphoric expression leading to the previous verbal argument is also compulsory.

\section{Acknowledgment}

The authors gratefully acknowledge support from the Czech Science Foundation (project $\mathrm{n}$. P406/12/0658), from the Ministry of Education, Youth and Sports (project LH14011) and support from the project "Discourse Connectives in Czech" (n. 36213) solved at the Faculty of Arts at the Charles University in Prague from the resources of the Charles University Grant Agency in 2013-2015. This work has been using language resources developed, stored and distributed by the LINDAT/CLARIN project of the Ministry of Education, Youth and Sports of the Czech Republic (project LM2010013).

\footnotetext{
${ }^{7}$ The note 0 (1) means that this token was finally interpreted as not relevant, i.e. not as AltLex because the anaphoric expression did not refer to the verbal but nominal node in this case. Therefore, this token (although provided with the comment AltLex) was excluded from the final number.
} 


\section{References}

Nicholas Asher. 1993. Reference to Abstract Objects in Discourse. Dordrecht: Kluwer Academic Publishers.

Eduard Bejček, Jarmila Panevová, Jan Popelka, Pavel Straňák, Magda Ševčíková, Jan Štěpánek, Zdeněk Žabokrtský. 2012. Prague Dependency Treebank 2.5 - a revisited version of PDT 2.0. In: Proceedings of the 24th International Conference on Computational Linguistics (Coling 2012), Bombay, India, pp. 231-246.

Jan Hajič, Jarmila Panevová, Eva Hajičová, Petr Sgall, Petr Pajas, Jan Štěpánek, Jiří Havelka, Marie Mikulová, Zdeněk Žabokrtský, and Magda Ševčíková-Razímová. 2006. Prague Dependency Treebank 2.0. Software prototype, Linguistic Data Consortium, Philadelphia, PA, USA, ISBN 1-58563-370-4, http://www.ldc.upenn.edu, Jul 2006.

Libuše Kroupová. 1984. Klasifikace sekundárních předložek z hlediska jejich tvoření. In: Naše řeč 67 (3), pp. 113116.

Anna Nedoluzhko, Jiří Mírovský, Eva Hajičová, Jiří Pergler, Radek Ocelák. 2011. Extended Textual Coreference and Bridging Relations in PDT 2.0. Data/software, UFAL MFF UK, Prague, Czech Republic, https://ufalpoint.mff.cuni.cz/xmlui/handle/11858/00-097C-0000-0005-BCCF-3, Dec 2011.

Anna Nedoluzhko. 2011. Rozšířená textová koreference a asociační anafora (Koncepce anotace českých dat v Pražském závislostním korpusu). Institute of Formal and Applied Linguistics, Prague, Czech Republic, ISBN 97880-904571-2-6, 268 pp., Dec 2011.

Petr Pajas, Jan Štěpánek. 2008. Recent advances in a feature-rich framework for treebank annotation. In Proceedings of the 22nd International Conference on Computational Linguistics (Coling 2008), Manchester, pp. 673-680.

Lucie Poláková, Pavlína Jínová, Šárka Zikánová, Eva Hajičová, Jiří Mírovský, Anna Nedoluzhko, Magdaléna Rysová, Veronika Pavlíková, Jana Zdeňková, Jiří Pergler, Radek Ocelák. 2012a. Prague Discourse Treebank 1.0. Data/software, ÚFAL MFF UK, Prague, Czech Republic, http://ufal.mff.cuni.cz/discourse/, Nov 2012.

Lucie Poláková, Pavlína Jínová, Šárka Zikánová, Zuzana Bedřichová, Jiří Mírovský, Magdaléna Rysová, Jana Zdeňková, Veronika Pavlíková, Eva Hajičová. 2012b. Manual for Annotation of Discourse Relations in the Prague Dependency Treebank. Technical Report No. 47, ÚFAL, Charles University in Prague.

Rashmi Prasad, Aravind Joshi, Bonnie Weber. 2010. Realization of Discourse Relations by Other Means: Alternative Lexicalizations. In: Proceedings of the 23rd International Conference on Computational Linguistics (Coling 2010), Tsinghua University Press, Beijing, China, pp. 1023-1031.

Rashmi Prasad, Nikhil Dinesh, Alan Lee, Eleni Miltsakaki, Livio Robaldo, Aravind Joshi and Bonnie Webber. 2008. The Penn Discourse Treebank 2.0. In: Proceedings of the 6th International Conference on Language Resources and Evaluation (LREC 2008), Marrakech, Morocco, pp. 2961-2968.

Magdaléna Rysová. 2012a. Alternative Lexicalizations of Discourse Connectives in Czech. In: Proceedings of the 8th International Conference on Language Resources and Evaluation (LREC 2012), European Language Resources Association, Istanbul, Turkey, ISBN 978-2-9517408-7-7, pp. 2800-2807.

Magdaléna Rysová. 2012b. Alternativni vyjádřeni konektorů v češtině. Master thesis, Faculty of Arts, Charles University in Prague, Czech Republic, 98 pp., Jun 2012.

Jan Štěpánek, Petr Pajas. 2010. Querying Diverse Treebanks in a Uniform Way. In: Proceedings of the 7th International Conference on Language Resources and Evaluation (LREC 2010), European Language Resources Association, Valletta, Malta, ISBN 2-9517408-6-7, pp. 1828-1835. 